\title{
Synthesis, antileishmanial activity and QSAR studies of 2-chloro- $\mathrm{N}$-arylacetamides
}

\author{
Stefânia Neiva Lavorato ${ }^{1}$, Mariana Costa Duarte ${ }^{2}$, Pedro Henrique Rocha De Andrade ${ }^{2,3}$, \\ Eduardo Antonio Ferraz Coelho ${ }^{2,3}$, Ricardo José Alves ${ }^{1, *}$
}

\begin{abstract}
${ }^{1}$ Departamento de Produtos Farmacêuticos, Faculdade de Farmácia, Universidade Federal de Minas Gerais, Belo Horizonte, MG, Brasil, '2 Departamento de Patologia Clínica, COLTEC, Universidade Federal de Minas Gerais, Belo Horizonte, MG, Brasil, ${ }^{3}$ Programa de Pós-Graduação em Ciências da Saúde Infectologia e Medicina Tropical, Faculdade de Medicina, Universidade Federal de Minas Gerais, Belo Horizonte, MG, Brasil
\end{abstract}

\begin{abstract}
We describe herein the synthesis and evaluation of the antileishmanial activity against promastigote forms of Leishmania amazonensis and cytotoxicity to murine macrophages of a series of 2-chloro- $N$ arylacetamide derivatives. All compounds were active, except one (compound $\mathbf{3}$ ). Compound $\mathbf{5}$ presented the most promising results, showing good antileishmanial activity $\left(\mathrm{CI}_{50}=5.39 \pm 0.67 \mu \mathrm{M}\right)$ and moderate selectivity ( $\mathrm{SI}=6.36$ ), indicating that further development of this class is worthwhile. Preliminary QSAR studies, although not predictive, furnished some insights on the importance of electronic character of aryl substituent to biological activity, as well as an indirect influence of hydrophobicity on activity.
\end{abstract}

Uniterms: Leishmaniasis/treatment. Chloroacetamides. Leishmania amazonensisChloroacetamides/ QSAR.

\section{INTRODUCTION}

Leishmaniasis is a neglected tropical disease caused by several species of Leishmania protozoa and transmitted to humans by the bite of the infected phlebotomine sandfly. This important public health problem affects about 12 million people worldwide, with an annual incidence of approximately 1.3 million new cases. Leishmaniasis is endemic in 98 countries, spread through Latin America, Africa, Asia and southern Europe (WHO, 2015).

There is no effective vaccine in preventing this disease and the available chemotherapy consists of pentavalent antimony compounds, paromomycin, pentamidine, amphotericin B and miltefosine, which are not satisfactory drugs for the treatment due to high toxicity and costs, as well as their parenteral administration for long periods and recent cases of resistance (Jain, Jain, 2013; McGwire, Satoskar, 2014). Therefore, the search for new cheap, potent and safe therapeutic alternatives is needed and has been pursued by several groups (Birhan,

*Correspondence: R. J. Alves. Departamento de Produtos Farmacêuticos. Faculdade de Farmácia. Universidade Federal de Minas Gerais. Avenida Antônio Carlos, 6627 - 31.270-901 - Belo Horizonte, MG, Brasil. Tel: +55 313409 6955; Fax: + 55313409 6935. E-mail: ricardodylan@farmacia.ufmg.br
Bekhit, Hymete, 2014; Coimbra et al., 2013; GómezPérez et al., 2014; Bonano et al., 2014; Gellis et al., 2012; Machado et al., 2012).

Several authors reported on the potential of 2-chloro- $N$-arylacetamide derivatives as herbicidal (Hamm, Speziale, 1956), antifungal (Aschale, 2012; Katke et al., 2011) and antibacterial agents (Aschale, 2012; Katke et al., 2011; Marco-Contelles, Gomez-Sanchez, 2005). Furthermore, these compounds have been widely used as intermediates for the synthesis of bioactive substances (Amrutkar et al., 2012; Siddiqui et al., 2010; Juddhawala, Parekh, Rawal, 2011; Jain et al., 2013; Harkov et al., 2013), highlighting the relevance of these compounds in pharmacological, agricultural and synthetic fields. Their biological activity is considered to result from alkylation of essential nucleophiles (Jaworski, 1969; Jablonkai, 2003), especially those containing thiol groups (Jaworski, 1956), such as glutathione and thiol-containing enzymes (Jablonkai, Hatzios, 1991; Jablonkai, Dutka, 1992).

Trypanosomatids present a unique thiol-based metabolism which protects these parasites against oxidative stress, ensuring their survival in a hostile environment (Krauth-Siegel, Comini, 2008). They also possess cysteine proteases, thiol-containing enzymes 
that are essential to life cycle and pathogenicity of the parasites (Vermelho et al., 2010), so inhibition of that metabolic pathway or these enzymes might impair the viability of trypanosomatids. The biological activity of 2-chloro- $N$-arylacetamides against trypanosomatids has not been described so far. It is likely that these compounds alkylate such pivotal targets, causing serious damages to parasites. Thus, in this work, we report the synthesis of ten 2-chloro- $N$-arylacetamide derivatives in order to evaluate their in vitro antileishmanial activity and calculate their half maximal inhibitory concentrations $\left(\mathrm{IC}_{50}\right)$ against Leishmania amazonensis. The cytotoxicity of the synthesized compounds to murine macrophages was also evaluated and their half maximal inhibitory concentrations $\left(\mathrm{CC}_{50}\right)$ against these cells were calculated. The selectivity index (SI) was also calculated based on the ratio between $\mathrm{CC}_{50}$ and $\mathrm{IC}_{50}$. We prepared compounds with different features regarding hydrophobic, steric and electronic characters, which would enable us to study qualitative and quantitatively, by QSAR (Quantitative Structure-Activity Relationship) analysis, the relationship between the structures of tested substances and their biological activity.

\section{MATERIAL AND METHODS}

General: All reactants and solvents were acquired from commercial suppliers and used without further purification. Melting points were determined on Microquímica MQAPF 301 apparatus. IR spectra were obtained on a Spectrum One, Perkin-Elmer ATR system. ${ }^{1} \mathrm{H}$ and ${ }^{13} \mathrm{C}$ NMR spectra were performed on a Bruker Avance DPX-200 spectrometer and the proton and carbon chemical shifts $(\delta)$ are given with respect to TMS.

Chemistry: Compounds 1-10 were synthesized as previously reported by Imamura et al. (2005). The yields ranged from 54 to $96 \%$. The compounds were fully characterized by their melting points and IR, ${ }^{1} \mathrm{H}$ and ${ }^{13} \mathrm{C}$ NMR spectra. The melting points of all compounds are consistent with previous reports (Harvill, Herbst, Schreiner, 1952; Youssef et al., 1976; Tropp, 1928; Basu, Sikdar, 1947; Harte, Gunnlaugsson, 2006; Singh, Hashim, Singhal, 2011).

Parasites: Leishmania amazonensis (IFLA/ BR/1967/PH-8) strain was used. Parasites were grown at $24{ }^{\circ} \mathrm{C}$ in Schneiderss medium (Sigma, St. Louis, MO, USA), supplemented with $20 \%$ heat-inactivated fetal bovine s33erum (FBS, Sigma), $20 \mathrm{mM}$ L-glutamine, $200 \mathrm{U} / \mathrm{mL}$ penicillin, and $100 \mu \mathrm{g} / \mathrm{mL}$ streptomycin, $\mathrm{pH}$ 7.4. Stationary-phase promastigotes were prepared as previously described (Coelho et al., 2013).
Mice: Peritoneal macrophages were obtained from female BALB/c mice ( 8 weeks old), which were purchased from the Institute of Biological Sciences (ICB) from UFMG, and maintained under specific pathogen-free conditions. The experimental protocol (code 136/2012) was approved by the Animal Use Committee from UFMG (CETEA/UFMG)

Antileishmanial activity: The inhibition of Leishmania growth was assessed in vitro by cultivating stationary-phase promastigotes of L. amazonensis $\left(1 \times 10^{6}\right.$ cells $)$ in the presence of each individual compound $(0$ to $100 \mu \mathrm{M})$, in 96 -well culture plates (Nunc, Nunclon ${ }^{\circledR}$, Roskilde, Denmark), for $48 \mathrm{~h}$ at $24^{\circ} \mathrm{C}$. A previous titration curve was performed to determine the best time of inhibition of L. amazonensis growth by incubating the parasites with the evaluated products for different periods (data not shown). Cell viability was assessed by measuring the cleavage of $2 \mathrm{mg} / \mathrm{mL}$ of MTT [3-(4,5-dimethylthiazol-2-yl)-2,5-diphenyl tetrazolium bromide] (Sigma). Absorbances were measured by using a multi-well scanning spectrophotometer (Molecular Devices, Spectra Max Plus, Canada), at a wavelength of $570 \mathrm{~nm}$. Amphotericin B (AmpB, $1 \mu \mathrm{M})$ was used as a positive control. The concentration of the compounds needed to inhibit $50 \%$ of the Leishmania viability $\left(\mathrm{IC}_{50}\right)$ was determined by applying the sigmoidal regression of the concentration-response curves, using different concentrations of the compounds. Data shown are representative of three independent experiments, performed in triplicate, which presented similar results.

Cytotoxicity assay: The inhibition of $50 \%$ of the macrophage viability $\left(\mathrm{CC}_{50}\right)$ was calculated by cultivating macrophages $\left(5 \times 10^{5}\right.$ cells $)$ in the presence of each individual compound ( 0 to $200 \mu \mathrm{M}$ ) in 96 -well plates for $48 \mathrm{~h}$, at $37^{\circ} \mathrm{C}$. A previous titration curve was performed to determine the best time of inhibition of macrophages viability by incubating the parasites with the evaluated products for different periods (data not shown). Cell viability was assessed by the MTT assay, and AmpB (1 $\mu \mathrm{M})$ was used as a control. The selectivity index (SI) was calculated by determining the ratio between $\mathrm{CC}_{50}$ and $\mathrm{IC}_{50}$. Data shown are representative of three independent experiments, performed in triplicate, which presented similar results.

Statistical analysis: Data were analyzed using the GraphPad Prism software (version 5.0 for Windows). The difference among the groups was evaluated by the one-way ANOVA, followed by Bonferroni's post-test for multiple 
comparisons. Differences were considered significant when $P<0.05$.

QSAR: QSAR regression analyses were executed with BuildQSAR program (Oliveira, Gaudio, 2001) and Multiple Linear Regression (MLR) was employed. 2D-QSAR study was performed using as biological parameter $\log \left(1 / \mathrm{IC}_{50}\right)$, derived from $\mathrm{IC}_{50}$ values for active compounds. $C \log P$ and the phenyl substituent constants $\sigma_{R}$ and $\mathrm{MR}_{\mathrm{R}}$ were evaluated as physicochemical descriptors. Briefly, $\mathrm{C} \log \mathrm{P}$ is the calculated octanol-water partition coefficient, $\sigma_{R}$ is Hammet's electronic constant and the $\mathrm{MR}_{\mathrm{R}}$ is the contribution of substituent to molar refractivity, being dependent on volume and polarizability. ClogP was calculated by MarvinSketch 5.9.3 (ChemAxon, 2012) and the substituent constants $\sigma_{R}$ and $M_{R}$ were obtained from Hansch and Leo (1979).

\section{RESULTS AND DISCUSSION}

Compounds 1-10 were prepared according to Imamura et al. (2005), by reacting the appropriate aniline with 2-chloroacetic anhydride in THF, at room temperature (Figure 1).

We evaluated the in vitro antileishmanial activity of compounds 1-10 against stationary-phase promastigote forms of L. amazonensis and the results are shown in Table I. Except for compound 3, all 2-chloro- $N$-arylacetamide derivatives showed significant antileishmanial activity. The most active compounds were $\mathbf{2}, \mathbf{5}$ and $\mathbf{8}$, with $\mathrm{IC}_{50}$ values below $6 \mu \mathrm{M}$. Interestingly, these compounds possess in common an electron-withdrawing aryl substituent, which<smiles>[R]c1ccc(N)cc1</smiles><smiles>[R]c1ccc(NC(=O)CCl)cc1</smiles>

$$
\begin{aligned}
& \text { 1: } \mathrm{R}=\mathrm{H} \\
& \text { 2: } \mathrm{R}=\mathrm{COOCH} \mathrm{CH}_{3} \\
& \text { 3: } \mathrm{R}=\mathrm{COOH} \\
& \text { 4: } \mathrm{R}=\mathrm{SO}_{2} \mathrm{NH}_{2} \\
& \text { 5: } \mathrm{R}=\mathrm{COCH}_{3}
\end{aligned}
$$

6: $\mathrm{R}=\mathrm{Cl}$

7: $\mathrm{R}=\mathrm{Br}$

8: $\mathrm{R}=\mathrm{NO}_{2}$ 9: $\mathrm{R}=\mathrm{CH}_{3}$ 10: $\mathrm{R}=\mathrm{OCH}_{3}$

FIGURE 1 - Synthesis of 2-chloro- $N$-arylacetamide derivatives 1-10.

may contribute to improve their potential as alkylating agents, by increasing the electrophilic character of the carbon alpha to chloro atom by resonance effect.

The cytotoxicity of compounds was determined using macrophages derived from female BALB/c mice and the values of $\mathrm{CC}_{50}$ are shown in Table I. The selectivity index (SI) for each compound (the ratio between the $\mathrm{CC}_{50}$ and $\mathrm{IC}_{50}$ values) was calculated and the data are also shown in Table I. According to Pires et al. (2013), a SI value above 10 is recommended to ensure the safety of a compound. The most selective 2-chloro- $N$-arylacetamide derivative was the compound $\mathbf{5}$, with a SI of 6.36. Since these compounds probably act as alkylating agents, this result indicates that the compound $\mathbf{5}$ could alkylate parasite nucleophiles with a moderate selectivity when compared with mammalian cell nucleophiles.

In order to study quantitatively the relationship between physicochemical properties of synthesized

TABLE I - Antileishmanial activity $\left(\mathrm{IC}_{50}\right)$, cytotoxicity profile $\left(\mathrm{CC}_{50}\right)$ and selectivity index $(\mathrm{SI})$ of compounds $\mathbf{1 - 1 0}$

\begin{tabular}{lccc}
\hline Compounds & $\mathbf{I C}_{\mathbf{5 0}} \pm \mathbf{S D}(\boldsymbol{\mu M})^{\mathbf{a}}$ & $\mathbf{C C}_{\mathbf{5 0}} \pm \mathbf{S D}(\boldsymbol{\mu M})^{\mathbf{b}}$ & $\mathbf{S I}^{\mathbf{c}}$ \\
\hline $\mathbf{1}$ & $11.41 \pm 6.05$ & $46.37 \pm 4.29$ & 4.06 \\
$\mathbf{2}$ & $4.74 \pm 0.20$ & $18.52 \pm 3.89$ & 3.91 \\
$\mathbf{3}$ & Inactive & $\mathrm{ND}^{\mathrm{d}}$ & $\mathrm{ND}^{\mathrm{d}}$ \\
$\mathbf{4}$ & $14.42 \pm 2.13$ & $22.84 \pm 8.70$ & 1.58 \\
$\mathbf{5}$ & $5.39 \pm 0.67$ & $34.28 \pm 16.66$ & 6.36 \\
$\mathbf{6}$ & $11.88 \pm 0.80$ & $17.99 \pm 1.66$ & 1.51 \\
$\mathbf{7}$ & $11.91 \pm 0.57$ & $17.71 \pm 4.89$ & 1.49 \\
$\mathbf{8}$ & $4.78 \pm 1.22$ & $18.50 \pm 0.13$ & 3.87 \\
$\mathbf{9}$ & $18.84 \pm 10.86$ & $29.95 \pm 4.08$ & 1.59 \\
$\mathbf{1 0}$ & $21.01 \pm 7.33$ & $25.15 \pm 0.21$ & 1.20 \\
$\mathbf{A m p B}^{\mathbf{e}}$ & $0.1 \pm 0.02$ & $0.78 \pm 0.21$ & 8.0 \\
\hline
\end{tabular}

${ }^{a} \mathrm{IC}_{50}: 50 \%$ inhibitory concentration on $L$. amazonensis promastigotes; ${ }^{\mathrm{b}} \mathrm{CC}_{50}: 50 \%$ cytotoxicity concentration on macrophages; 'SI: selective index $\left(\mathrm{CC}_{50} / \mathrm{IC}_{50}\right)$; ${ }^{\mathrm{d}} \mathrm{ND}=$ not determined; ${ }^{\mathrm{e}} \mathrm{AmpB}=\mathrm{Amphotericin} \mathrm{B}$, positive control. 
compounds and their antileishmanial activity, a 2D-QSAR study was performed. The hydrophobic, electronic and steric parameters were evaluated using $\mathrm{C} \log \mathrm{P}$ and the phenyl substituent constants $\sigma_{R}$ and $M_{R}$, respectively. $\mathrm{IC}_{50}$ values of active compounds were converted into log $\left(1 / \mathrm{IC}_{50}\right)$ and used as biological parameters in the QSAR study (Table II).

The data set consists of nine points. We evaluated different linear models with one or two independent variables to obey the condition $n / p \geq 4$, where $n$ is the number of data points and $p$ is the number of descriptors used in QSAR model (Verma, Hansch, 2010). The MLR module of BuildQSAR program was used (Oliveira, Gaudio, 2001). The obtained QSAR models with statistical parameters are shown in Table III.

To determine which QSAR model better describes our data, we evaluated several statistical parameters, such as the fraction of variance $\left(r^{2}\right)$, the correlation coefficient $(r)$ and the measure of statistical significance $(p)$. Among the QSAR models, we found the best correlation between independent and dependent variables with model 1 . In this model, the compound $\mathbf{4}$ was considered an outlier. Among the predicted QSAR equations, model 1 presented the highest $r^{2}$ value, indicating that this model can explain the activity variation in a higher percentage. Moreover, the low value of $p$ indicates a higher statistical significance of the model regarding the others. The data of observed activity values and predicted activity values (calculated using model 1) is given in Table II.

By the model 1, a good correlation between the antileishmanial activity of this class and Hammet's electronic constant was observed. This constant represents

TABLE II - Physicochemical parameters and observed and calculated biological activity

\begin{tabular}{|c|c|c|c|c|c|c|c|}
\hline \multirow{2}{*}{ Compounds } & \multirow{2}{*}{$\mathbf{R}$} & \multicolumn{3}{|c|}{$\log \left(1 / \mathrm{IC}_{50}\right)^{\mathrm{a}}$} & \multirow{2}{*}{$C \log P^{c}$} & \multirow{2}{*}{$\sigma_{R}^{d}$} & \multirow{2}{*}{$\mathbf{M R}_{\mathrm{R}}{ }^{\mathrm{e}}$} \\
\hline & & Obs. & Calc. $^{\mathrm{b}}$ & $\Delta$ & & & \\
\hline 1 & $\mathrm{H}$ & 4.94 & 4.865 & 0.075 & 1.75 & 0 & 1.03 \\
\hline 2 & $\mathrm{COOCH}_{2} \mathrm{CH}_{3}$ & 5.36 & 5.178 & 0.182 & 2.11 & 0.45 & 17.49 \\
\hline 3 & $\mathrm{COOH}$ & - & - & - & $-1.66^{\mathrm{f}}$ & 0.45 & 6.93 \\
\hline $4^{g}$ & $\mathrm{SO}_{2} \mathrm{NH}_{2}$ & 4.84 & 5.262 & -0.422 & $0.35^{\mathrm{f}}$ & 0.57 & 12.28 \\
\hline 5 & $\mathrm{COCH}_{3}$ & 5.27 & 5.213 & 0.057 & 1.31 & 0.50 & 11.18 \\
\hline 6 & $\mathrm{Cl}$ & 4.93 & 5.025 & -0.095 & 2.35 & 0.23 & 6.03 \\
\hline 7 & $\mathrm{Br}$ & 4.92 & 5.025 & -0.105 & 2.52 & 0.23 & 8.88 \\
\hline 8 & $\mathrm{NO}_{2}$ & 5.32 & 5.408 & -0.088 & 1.69 & 0.78 & 7.36 \\
\hline 9 & $\mathrm{CH}_{3}$ & 4.72 & 4.747 & -0.027 & 2.26 & -0.17 & 5.65 \\
\hline 10 & $\mathrm{OCH}_{3}$ & 4.68 & 4.678 & 0.002 & 1.59 & -0.27 & 7.87 \\
\hline
\end{tabular}

${ }^{\mathrm{a}} \mathrm{CC}_{50}: 50 \%$ inhibitory concentration on L. amazonensis promastigotes; ${ }^{\mathrm{b} D a t a}$ calculated using model 1 (Table III); ${ }^{\mathrm{c}} \mathrm{ClogP}$ : calculated partition coefficient, calculated by MarvinSketch 5.9.3 (ChemAxon, 2012); ${ }^{\mathrm{d}} \sigma_{\mathrm{R}}$ : Hammet's electronic constant, obtained from Hansch, Leo, 1979; ${ }^{\mathrm{e}} \mathrm{MR}_{\mathrm{R}}$ : molar refractivity, obtained from Hansch and Leo, 1979; ${ }^{\mathrm{f}}$ at $\mathrm{pH} 7.4 ;{ }^{\mathrm{g}}$ Outlier.

TABLE III - QSAR models with statistical parameters.

\begin{tabular}{|c|c|c|c|c|c|c|}
\hline & Regression equation & $n / p^{\mathrm{a}}$ & $r^{b}$ & $r^{2 c}$ & $p^{e}$ & Outlier \\
\hline 1 & $\log \left(1 / \mathrm{IC}_{50}\right)=0.6949( \pm 0.2817) \sigma_{\mathrm{R}}+4.8655( \pm 0.1122)$ & 8 & 0.927 & 0.859 & 0.0009 & 4 \\
\hline 2 & $\log \left(1 / \mathrm{IC}_{50}\right)=0.0059( \pm 0.3455) \mathrm{Clog} \mathrm{P}+4.9873( \pm 0.6485)$ & 9 & 0.015 & 0.0002 & 0.9689 & - \\
\hline 3 & $\log \left(1 / \mathrm{IC}_{50}\right)=0.0263( \pm 0.0431) \mathrm{MR}_{\mathrm{R}}+4.7701( \pm 0.4184)$ & 9 & 0.479 & 0.230 & 0.1920 & - \\
\hline$\overline{4}$ & $\begin{array}{c}\log \left(1 / \mathrm{IC}_{50}\right)=0.6521( \pm 0.4272) \sigma_{\mathrm{R}}+0.1314( \pm 0.2271) \mathrm{Clog} \mathrm{P}+ \\
4.5972( \pm 0.4726)\end{array}$ & 4.5 & 0.836 & 0.699 & 0.0272 & - \\
\hline 5 & $\begin{array}{c}\log \left(1 / \mathrm{IC}_{50}\right)=0.5166( \pm 0.5207) \sigma_{\mathrm{R}}+0.0071( \pm 0.0394) \mathrm{MR}_{\mathrm{R}}+ \\
4.8037( \pm 0.3338)\end{array}$ & 4.5 & 0.782 & 0.611 & 0.0587 & - \\
\hline 6 & $\begin{array}{c}\log \left(1 / \mathrm{IC}_{50}\right)=0.0280( \pm 0.0490) \mathrm{MR}_{\mathrm{R}}+0.0516( \pm 0.3446) \mathrm{Clog} \mathrm{P}+ \\
4.6642( \pm 0.8457)\end{array}$ & 4.5 & 0.496 & 0.246 & 0.4281 & - \\
\hline
\end{tabular}

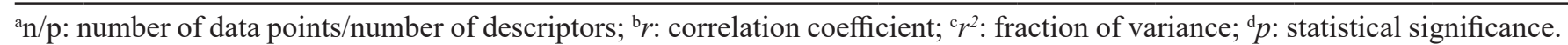


the electronic effect of a particular substituent. Positive $\sigma_{R}$ values mean that the group has an electron withdrawing effect and negative values mean that the group has an electron donating effect. The parameter $r^{2}$ indicates that this model can explain $85.9 \%$ of activity variation. The $p$-value indicates a statistical significance of $99.91 \%$.

Since we worked with a small data set and the external validation of QSAR models could not be done, the obtained model does not have a predictive value. However, the correlation found between the antileishmanial activity and Hammet's electronic constant $\left(\sigma_{R}\right)$ can help us to get some insights about the mechanism of action of these compounds. The positive coefficient of $\sigma_{\mathrm{R}}$ means a direct correlation between the dependent and independent variables, corroborating previous observations that structurally-related compounds bearing electron-withdrawing groups present greater activity than those with electron donating groups (Céspedes-Camacho et al., 2012; Neau et al., 1982). Although compound 4 $\left(\mathrm{R}=\mathrm{SO}_{2} \mathrm{NH}_{2}\right)$ presents a substituent with high positive value of $\sigma_{R}$, it does not follow this tendency, behaving like an outlier. This could be explained by its lower hydrophobicity, indicated by its low value of ClogP (0.35), which may be hindering its passage across the lipophylic membranes of parasite. In the same way, one could suggest a reason why the compound $\mathbf{3}$ was inactive. In physiological $\mathrm{pH}$, the carboxylic group of compound $\mathbf{3}$ is predominantly ionized. Then, if we consider the ionized forms in calculating partition coefficient, we obtain a $\mathrm{C} \log \mathrm{P}$ (or calculated distribution coefficient - ClogD) of -1.66 . This suggests that hydrophobicity could also affect the activity when compounds present low values of ClogP, although the high $\sigma_{R}$ value. This observation is in accordance with Jablonkai (2003), which demonstrates that the herbicidal activity of chloracetamides is not simply dependent on chemical reactivity, but related to molecular properties, including lipophilicity.

\section{CONCLUSION}

In conclusion, we have described herein the synthesis and evaluation of the antileishmanial activity against promastigote forms of $L$. amazonensis and cytotoxicity to murine macrophages of ten 2-chloro- $N$-arylacetamide derivatives. All compounds, but one, present good antileishmanial activity, demonstrating for the first time the biological potential of this class against Leishmaniasis. Moreover, compound $5\left(\mathrm{R}=\mathrm{COCH}_{3}\right)$ showed the most promising results, with good antileishmanial activity and moderate selectivity. By QSAR studies, the influence of electronic character of aryl substituent to biological activity was demonstrated. The indirect influence of hydrophobicity on this activity was also observed. In view of the promising antileishmanial activity of some compounds of this class, the synthesis of analogues possessing high SI is worthwhile. Work in this direction is underway and the results will be reported in due time.

\section{ACKNOWLEDGEMENTS}

Authors would like to thank the CNPq, CAPES, FAPEMIG and INCT Nanobiofar for their financial support. E.A.F. Coelho and R.J. Alves are grant recipient of CNPq.

\section{REFERENCES}

AMRUTKAR, S.V.; KHAIRNAR, M.V.; RANAWAT, M.S.; WAGH, D.N. Synthesis, characterization and biological evaluation of 2-[(2'-ethyl-4'-oxoquinazolin-3'-yl)amino$N$-aryl acetamide derivatives. Int. J. Drug Design Disc.IJDDD, v.3, p.846-850, 2012.

ASCHALE, M. Synthesis and antimicrobial evaluation of some novel substituted 2-chloroacetanilides. Int. J. ChemTech. Res., v.4, p.1437-1441, 2012.

BASU, U.P.; SIKDAR, J. Aurothiacyl compounds from sulfa drugs. J. Indian Chem. Soc., v.24, p.466-468, 1947.

BIRHAN, Y.S.; BEKHIT, A.A.; HYMETE, A. Synthesis and antileishmanial evaluation of some 2,3-disubstituted4(3H)-quinazolinone derivatives. Org. Med. Chem. Lett., v.4, p.10, 2014.

BONANO, V.I.; YOKOYAMA-YASUNAKA, J.K.U.; MIGUEL, D.C.; JONES, S.A.; DODGE, J.A.; ULIANA, S.R.B. Discovery of Synthetic Leishmania Inhibitors by Screening of a 2-Arylbenzothiophene Library. Chem. Biol. Drug Des., v.81, p.658-665, 2014.

CÉSPEDES-CAMACHO, I.F.; MANSO, J.A.; GONZÁLEZJIMÉNEZ, M.; CALLE, E.; CASADO, J. The reactivity of vinyl compounds as alkylating agents. Monatsh Chem., v.143, p.723-727, 2012.

CHEMAXON. MarvinSketch version 5.9.3 developed by ChemAxon. 2012. Avalilabe from: $<$ http://www.chemaxon. com/products/marvin/marvinsketch/>.Access in: May, 2016. 
COELHO, E.A.; TAVARES, C.A.P.; CARVALHO, F.A.A.; CHAVES, K.F.; TEIXEIRA, K.N.; RODRIGUES, R.C.; CHAREST, H.; MATLASHEWSKI G.; GAZZINELLI, R.T.; FERNANDES, A.P. Immune responses induced by the Leishmania (Leishmania) donovani A2 antigen, but not by the LACK antigen, are protective against experimental Leishmania (Leishmania) amazonensis infection. Infect. Immun., v.71, p.3988-3994, 2013.

COIMBRA, E.S.; ANTINARELLI, L.M.R.; SILVA, A.D.; BISPO, M.L.F.; KAISER, C.R.; DE SOUZA, M.V.N. 7-Chloro-4-quinolinyl hydrazones: a promising and potent class of antileishmanial compounds. Chem. Biol. Drug. Des., v.81, p.658-665, 2013.

OLIVEIRA, D.B.; GAUDIO, A.C. BuildQSAR: a new computer program for QSAR analysis. Quant. Struct-Activ. Relat., v.19, p.599-601, 2001.

GELLIS, A.; DUMÈTRE, A.; LANZADA, G.; HUTTER, S.; OLLIVIER, E.; VANELLE, P.; AZAS, N. Preparation and antiprotozoal evaluation of promising $\beta$-carboline alkaloids. Biomed. Pharmacother., v.66, p.339-347, 2012.

GÓMEZ-PÉREZ, V.; MANZANO, J.I.; GARCÍAHERNANDÉZ, R.; CASTANYS, S.; ROSA, J.M.C.; GAMARRO, F. 4-Amino bis-pyridinium derivatives as novel antileishmanial agentes. Antimicrob. Agents Chemother, v.58, p.4103-4112, 2014.

HAMM, P.C.; SPEZIALE, A.J. Relation of herbicidal activity to the amide moiety of $N$-substituted alpha-chloroacetamides. J. Agric. Food Chem., v.4, p.518, 1956.

HANSCH, C.; LEO, A. Substituent constants for correlation analysis in chemistry and biology. New York: Wiley, 1979. 339 p.

HARKOV, S.; HAVRYLYUK, D.; ATAMANYUK, V.; ZIMENKOVSKY, B.; LESYK, R. Synthesis and biological activity of isatines bearing thiazolidinone and pyrazoline moieties. Pharmacia, v.60, p.8-18, 2013.

HARTE, A.J.; GUNNLAUGSSON, T. Synthesis of $\alpha$-chloroamides in water. Tetrahedron Lett., v.47, p.63216324, 2006.

HARVILL, E.K.; HERBST, R.M.; SCHREINER, E.G. Haloalkyltetrazole and aminoalkyltetrazole derivatives. $J$. Org. Chem., v.17, p.1557-1616, 1952.
IMAMURA, S.; NISHIKAWA, Y.; ICHIKAWA, T.; HATTORI, T.; MATSUSHITA, Y.; HASHIGUCHI, S.; KANZAKI, N.; IIZAWA, Y.; BABA, M.; SUGIHARA, Y. CCR5 antagonists as anti-HIV-1 agents. Part 3: Synthesis and biological evaluation of piperidine-4-carboxamide derivatives. Bioorg. Med. Chem., v.13, p.397-416, 2005.

JABLONKAI, I. Alkylating reactivity and herbicidal activity of chloroacetamides. Pest. Manag. Sci., v.59, p.443-450, 2003.

JABLONKAI, I.; DUTKA, F. Preparative-scale synthesis and physicochemical properties of cysteine and glutathione conjugates of chloroacetamides. J. Agric. Food Chem., v.40, p.506-508, 1992.

JABLONKAI, I.; HATZIOS, K.K. Role of glutathione and glutathione $s$-transferase in the selectivity of acetochlor in maize and wheat. Pestic. Biochem. Phys., v.41, p.221-231, 1991.

JAIN, K.; JAIN, N.K. Novel therapeutic strategies for treatment of visceral leishmaniasis. Drug Discov. Today, v.18, p.1272$1281,2013$.

JAIN, N.P.; UPASANI, C.D.; KALKOTWAR, R.S.; JAIN, U.N. Synthesis and anti-inflammatory activity of $N$-(Alkyl or Aryl)-2-(1H-benzotriazol-1-yl)acetamide derivatives. Res. J. Pharm. Biol. Chem. Sci., v.4, p.1470-1480, 2013.

JAWORSKI, E.G. Biochemical action of CDAA, a new herbicide. Science, v.123, p.847-848, 1956.

JAWORSKI, E.G. Analysis of the mode of action of herbicidal $\alpha$-chloroacetamides. J. Agr. Food Chem., v.17, p.165-170, 1969.

JUDDHAWALA, K.V.; PAREKH, N.M.; RAWAL, B.M. Synthesis and antibacterial activities of $N$-chloro aryl acetamide substituted thiazole and 2,4-thiazolidinedione derivatives. Arch. Appl. Sci. Res., v.3, p.540-548, 2011.

KATKE, S.A.; AMRUTKAR, S.V.; BHOR, R.J.; KHAIRNAR, M.V. Synthesis of biologically active 2-chloro- $N$-alkyl/ arylacetamide derivatives. Int. J. Pharm. Sci. Res., v.2, p.148-156, 2011.

KRAUTH-SIEGEL, R.L.; COMINI, M.A. Redox control in trypanosomatids, parasitic protozoa with trypanothionebased thiol metabolism. Biochim. Biophys. Acta, v.1780, p.1236-1248, 2008. 
MACHADO, P.A.; HILÁRIO, F.F.; CARVALHO, L.O.; SILVEIRA, M.L.T.; ALVES, R.B.; FREITAS, R.P.; COIMBRA, E.S. Effect of 3-Alkylpyridine marine alkaloid analogues in Leishmania species related to American cutaneous 1Leishmaniasis. Chem. Biol. Drug Des., v.80, p.745-751, 2012.

MARCO-CONTELLES, J.; GOMEZ-SANCHEZ, E. New agents with antimycobacterial activity. Arch. Pharm. Chem. Life Sci., v.338, p.562-563, 2005.

MCGWIRE, B.S.; SATOSKAR, A.R. Leishmaniasis: clinical syndromes and treatment. QJM., v.107, p.7-14, 2014.

NEAU, S.H.; HOOBERMAN, B.H.; FRANTZ, S.W.; SINSHEIMER, J.E. Substituent effects on the mutagenicity of phenyl glycidyl ethers in Salmonella typhimurium. Mutat. Res., v.93, p.297-304, 1982.

PIRES, C.L.; RODRIGUES, S.D.; BRISTOT, D.; GAETA, H.H.; TOYAMA, D.O.; FARIAS, W.R.L.; TOYAMA, M.H. Evaluation of macroalgae sulfated polysaccharides on the Leishmania (L.) Amazonensis promastigote. Mar. Drugs, v.11, p.934-943, 2013.

SIDDIQUI, N.; SHAQUIQUZZAMAN; RAHMAN, M.U.; ARSHAD, M.F.; AHSAN, W.; ALAM, M.S.; AHMED, S. Synthesis, characterization and antimicrobial evaluation of some new 1,3-thiazole-2,4-diamine derivatives. Acta Pol. Pharm., v.67, p.239-246, 2010.
SINGH, D.C.P.; HASHIM, S.R.; SINGHAL, R.G. Synthesis and antimicrobial activity of some new thioether derivatives of quinoxaline. E-J. Chem., v.8, p.635-642, 2011.

TROPP, C. Action of phosgene on polypeptide-like derivatives of p-aminobenzoic acid. Formation of 1,3-substituted hydantoins. Ber. Dtsch. Chem. Ges., v.61B, p.1431-1439, 1928.

VERMA, R.P.; HANSCH, C. QSAR modeling of taxane analogues against colon cancer. Eur. J. Med. Chem., v.45, p.1470-1477, 2010.

VERMELHO, A.B.; BRANQUINHA, M.H.; DAVILA-LEVY, C.M.; SANTOS, A.L.S.; DIAS, E.P.S.; MELO, A.C.N. Biological roles of peptidases in trypanosomatids. Open Parasitol. J., v.4, p.5-23, 2010.

WORLD HEALTH ORGANIZATION. WHO. Leishmaniasis. Available from: <http://www.who.int/mediacentre/ factsheets/fs375/en/>. Access on: Nov. 7, 2015.

YOUSSEF, A.F.; FARAG, H.H.; ABDELKADER, M.A.; ELGENDY, M.A. Unsymmetrical $N, N$-disubstituted anilines: synthesis of $\alpha$ - $(N$-methylanilino $)$ acetamides. Indian J. Chem. B. Org., v.14B, p.279-281, 1976.

Received for publication on $14^{\text {th }}$ April 2016 Accepted for publication on $27^{\text {th }}$ October 2016 